\title{
PEMERIKSAAN FRAUD \\ DALAM AKUNTANSI FORENSIK DAN AUDIT INVESTIGATIF
}

\author{
Annisa Sayyid \\ Fakultas Syariah dan Ekonomi Islam, IAIN Antasari Banjarmasin. \\ E-mail: zheefhanisa@yahoo.co.id
}

\begin{abstract}
Abstrak
The History of world bussiness is full of ethics violation cases and financial scandals. Public can even see clearly the various economic crimes such as corruption, financial engineering and money laundering. These issues are always interesting since it involves tricks in information presentation which indicates a fraud. The application of forensic accounting and investigative audits is a solution to the anxiety of financial world. Forensic accounting and investigative audits in its simplest form is a blend between the disciplines of accounting, auditing and law. Forensic accounting is the use of accounting skills combined with the ability to solve a problem or alleged fraud. The investigative audit is an attempt to prove a mistake in accordance with the provisions of applicable law.
\end{abstract}

Kata kunci: Fraud, kecurangan, akuntansi forensik, audit investigatif.

\section{Pendahuluan}

Sudah banyak dipahami bahwa telah terjadi perubahan konstelasi politik dan ekonomi dalam hubungan internasional dewasa ini.Coretan tinta sejarah dunia selalu memberi pelajaran pada kita bahwa perubahan besar selalu terjadi bersamaan dengan terjadinya krisis global.Kekuatan-kekuatan ekonomi baru muncul dan hubungan kekuatan antar bangsa pun berubah karena peristiwa besar yang didahului oleh krisis. Hal itu karena, respon terhadap krisis membuat banyak kekuatan dunia terpuruk, dan pun juga ada yang beruntung akan bisa bangkit kembali. ${ }^{1}$

Krisis keuangan telah membuat banyak implikasi negatif yang membuat masyarakat menderita.Kemiskinan merajalela, pengangguran melonjak, meningkatnya inflasi, kebangkrutan pusat industri serta daya beli

${ }^{1}$ Nurani Soyomukti dan Happy Nurwidiamoko, "Occupy Wall Street" Dari Krisis Sistem Keuangan Amerika Serikat Menuju Gerakan Massa Anti-Neoliberalisme, (Malang: Intrans Publishing, 2012), h.1. 
masyarakat menjadi turun. Hal ini pada akhirnya mendorong tumbuhnya ketidakpercayaan publik pada pemerintah dan lembaga keuangan terkait.Krisis ini seperti fenomena bom waktu yang bisa meledak kapanpun dan dimanapun.Bahkan, publik dapat menyaksikan secara gamblang berbagai tindak kejahatan keuangan yang terjadi yaitu seperti korupsi, rekayasa keuangan serta tindak pidana pencucian uang diberbagai bidang.

Kalau kita ingat, meskipun Amerika Serikat telah berhasil mengatasi Great Depression pada tahun 1930, namun ternyata pada awal tahun 2001, gelembung soko guru perekonomian dunia tersebut, Negeri Paman Sam pecah, meledak berserakan kemana-mana membuat orang sedunia terperangah. ${ }^{2}$ Menjalar menjadi krisis diseluruh dunia. Diawali dengan kebangkrutan Enron Corporation, perusahaan raksasa dibidang energi yang melakukan akrobat akuntansi dengan menyulap pendapatan sebesar USD600 juta dan menyembunyikan hutang sejumlah USD1,2 Miliar. ${ }^{3}$ Kemudian Lehman Brothers cs yang melakukan trik memelihara SIV (Stucture Investment Vebicle) yang sebenarnya tak pernah ada. ${ }^{4}$ Diikuti lagi dengan limbungnya Citigroup yang pada kenyataannya merugi USD50 Miliar dalam neraca keuangannya. Sehingga menimbulkan krisis ekonomi berkepanjangan.Layaknya Dejavu 1929, dimana pasar modal Amerika ambruk atau yang lebih dikenal dengan Black Tuesday. ${ }^{5}$

Tidak hanya dalam entitas atau perusahaan saja, kasus kecurangan akuntansi (fraud) juga menimpa beberapa lembaga keuangan dan perbankan

${ }^{2}$ Filantropis George Soros mengatakan bahwa gaya Amerika dalam upaya menyelesaikan krisis adalah dengan krisis. Dengan kata lain, Persoalan diselesaikan dengan masalah baru yang lebih besar. Lihat Muhammad Ma'ruf, Tsunami Finansial: Peluang Bisnis dan Investasi Indonesia dan setiap Individu di Tahun 2009 (Jakarta: Penerbit Hikmah, 2009), h.xii.

3D. J, Barreveld, The Enron Collapse: Creative Accounting, Wrong Economic, or Criminal Acts, New York: Writer Club Press, 2002.

${ }^{4}$ Muhammad Ma'ruf, Tsunami Finansial: Peluang Bisnis dan Investasi Indonesia dan setiap Individu di Tabun 2009, h.63.

5Tinta Sejarah ekonomi modern mencatat adanya peristiwa "Selasa Kelabu" atau lebih dikenal dengan Black Tuesday .Selasa Kelabu atauBlack Tuesday adalah awal krisis ekonomi paling berat yang pernah ada.Black Tuesday terjadi pada tanggal 29 Oktober 1929, yaitu peristiwa ambruknya pasar modal Amerika Serikat.Masa sesudahnya dijuluki The Great Depression karena pasar dan perekonomian mengalami depresi berat, inflasi melonjak sehingga rata-rata penghasilan terpangkas separuhnya.Akibatnya banyak bank bangkrut dan uang nasabah tak kembali.Pusat-pusat industri gulung tikar dan pengangguran meledak hingga 25\%.Krisis ini merambat ke negara-negara lain seperti Australia, Jerman, Perancis, Kanada, Belanda, Asia, Amerika Latin hingga benua Afrika. 
dunia.Seperti Kasus skandal Subprime Mortgage, atau kredit rumah dengan agunan yang tidak sesuai standar. Di Indonesia, adalah Kasus Bank Century yang merugikan negara hampir 6,7 Triliun. Selain itu juga banyak terdapat kasuskecurangan akuntansi yang terjadi pada tahun 2010-2011. Jumlah kerugian akibat kasus-kasus tersebut mencapai lebih dari Rp100 miliar. Bentukbentuk kecurangan atau fraud tersebut antara lain seperti pemberian kredit dengan dokumen keuangan palsu, jaminan fiktif, pencairan deposito secara sepihak serta tindakan-tindakan kecurangan lainnya.

Krisis ini juga telah menyebabkan persaingan usaha menjadi semakin ketat. ${ }^{6}$ Tuntutan persaingan ini dapat mengubah perilaku bisnis ke arah persaingan yang tidak sehat/curang yang merupakan salah satu bentuk kejahatan ekonomi (economic crime). ${ }^{7}$ Keadaan ini memaksa kemungkinan terjadi banyaknya pelanggaran dan penyimpangan yang pada gilirannya akan menimbulkan konsekuensi besar yang akhirnya dapat merugikan banyak pihak yaitu terjadinya masalah kecurangan (fraud). Kecurangan atau Fraud adalah tindakan penipuan yang disengaja, umumnya dalam bentuk suatu kebohongan, penjiplakan dan pencurian. ${ }^{8}$

Salah satu respons positif guna mencegah maraknya terjadinya tindakan kecurangan atau fraud di dunia bisnis, adalah deteksi dini berupa adanya prosedur pemeriksaan secara akuntansi dan secara hukum yang akhirakhir ini lebih populer dengan nama akuntansi forensik dan audit investigatif. Secara sederhana, akuntansi forensik dan audit investigatif adalah perpaduan antara tiga disiplin ilmu yaitu ilmu akuntansi, ilmu audit serta ilmu hukum.

Tingkat minat terhadap akuntansi forensik dan audit investigatif berkembang pesat, terutama dikalangan penegak hukum, akademisi dan mahasisiwa program profesi akuntansi. Pemberitaan media massa menambah keingintahuan masyarakat mengenai upaya pencegahan dan penindakan

${ }^{6}$ Salah satu prinsip ekonomi klasik adalah mencari keuntungan yang setinggi-tingginya dengan pengorbanan yang sekecil-kecilnya.Prinsip ekonomi ini tentunya masih terbuka untuk diperdebatkan, terutama bila dikaitkan dengan pembangunan ekonomi dalam suatu negara yang bertujuan untuk menciptakan keadilan dan kemakmuran bersama.

${ }^{7}$ Istilah kejahatan ekonomi atau economic crime adalah kejahatan terhadap ekonomi atau kejahatan yang merugikan dalam bidang ekonomi. Lihat Ramli Atmasasmita, Pengantar Hukum Kejahatan Bisnis (Jakarta : Prenada Media, 2003), h. xvi. Lihat pula Adrianus Meliala, Praktek Bisnis Curang (Jakarta: Sinar Harapan, 1993), h. 140.

${ }^{8}$ Amin Widjaja, Forensic \& Investigative Accounting: Pendekatan Kasus(Jakarta: HARVARINDO, 2012), h. 1. 
terhadap korupsi, yang secara langsung hal itu berkenaan dengan akuntansi forensik dan audit investigatif.

Di dalam negeri terdapat pemberitaan bertubi-tubi mengenai pemberian uang suap kepada oknum penegak hukum, oknum anggota Dewan Perwakilan Rakyat, oknum pimpinan pemerintahan pusat dan daerah, serta oknum komisioner dan lain sebagainya. Juga pemberitaan mengenai berbagai kasus korupsi yang melibatkan petinggi Bank Indonesia.

Sementara itu, di luar negeri ada pemberitaan Bernard ("Bernie") Madoff dan Ponzi scheme-nya yang sejak tahun 2001 terendus oleh akuntan forensik Harry Marcopolus dan jurnalis investigatif Erin Arvendlund.Pihak U.S. SEC dan FBI mengetahuinya dari Madoff setelah delapan tahun kemudian.Fraud yang berjalan selama 30 tahun ini diperkirakan menelan kerugian kurang lebih U.S \$65Milliar.

Berdasarkan keberhasilan penanganan kasus-kasus besar tersebut, maka akuntansi forensik serta audit investigatif merupakan solusi utama guna mencegah terjadinya fraud yang merugikan banyak pihak dengan jumlah nominal yang tidak sedikit. Akuntansi Forensik serta audit investigatif merupakan jawaban atas tantangan tersebut. Sifat "Problem-Based" dari kedua disiplin ilmu ini diharapkan dapat menjadi solusi masalah-masalah kecurangan yang saat ini banyak ditemukan terjadi di berbagai entitas baik di lingkup nasional maupun internasional. ${ }^{10}$

Mengingat fenomena ini masih tergolong relatif baru, tentunya masih banyak pihak-pihak yang belum memahami apa sebenarnya yang dimaksud dengan pemeriksaan fraud, akuntansi forensik ataupun audit investigatif tersebut. Mengapa akuntansi forensik serta audit investigatif sangat diperlukan?. Bagaimana peranannya dalam praktek menyingkap ada tidaknya fraud atau kecurangan dalam suatu entitas atau perusahaan serta dalam lembaga keuangan dan perbankan?.Inilah serangkaian pertanyaan mendasar cikal bakal lahirnya gagasan tulisan ini. Sekaligus tantangan dari uraian di atas yang akancoba dijawab dalam tulisan tentang pemeriksaan fraud dalam akuntansi forensik serta audit investigatif berikut ini.

${ }^{9}$ Lihat Theodorus M Tuanakotta, Akuntansi Forensik dan Audit Investigatif, edisi kedua (Jakarta: Salemba Empat, 2010), h. 32.

${ }^{10}$ Bahkan di luar negeri, akuntansi forensik telah menjadi disiplin ilmu akuntansi yang umum digunakan. Contoh penerapan akuntansi forensik adalah salah satu kasus yang menghebohkan di Amerika Serikat yang terkenal dengan Enron Gate dan Worldcom Gate, terungkap antara lain berkat penggunaan Fraud Account dalam teknik auditnya. Lihat Dedhy S, Yeni J, Liza A, Creative Accounting:Mengungkap Manajemen Laba dan Skandal Akuntansi, h. 59. 


\section{Fraud.}

Istilah Fraud memang masih terdengar asing ditelinga kita. Namun dalam konteks dunia akuntansi forensik dan audit investigatif, Fraud adalah sasaran operasi utamanya. Frand atau dalam bahasa Indonesia lebih dikenal dengan kecurangan adalah objek utama yang diperangi dalam akuntansi forensik dan dibuktikan dalam audit investigatif. Kecurangan adalah suatu pengertian umum yang mencakup beragam cara yang dapat digunakan oleh kecerdikan manusia, yang digunakan seseorang untuk mendapatkan keuntungan dari orang lain melalui perbuatan yang tidak benar. Kecurangan adalah penipuan yang disengaja, umumnya dalam bentuk kebohongan, penjiplakan dan pencurian.Kecurangan dilakukan untuk memperoleh keuntungan berupa uang dan kekayaan, atau untuk menghindari pembayaran atau kerugian jasa, menghindari pajak serta mengamankan kepentingan pribadi atau usaha.

Selain pengertian di atas, ada pula beberapa macam pengertianfraud atau kecurangan lainnya, yaitu sebagai berikut.

a. Menurut TommieW. Singleton dan Aaron J, kecurangan adalahperbuatan mencakup akal muslihat, kelicikan, dan tidak jujur dan cara-cara yang tidak layak/wajar untuk menipu orang lain untuk keuntungan diri sendiri, sehingga menimbulkan kerugian bagi pihak lain. ${ }^{11}$

b. Menurut G. Jack Bologna, Robert J. Lindquist dan Joseph T. Wells, Kecurangan adalah penipuan kriminal yang bermaksud memberi manfaat keuangan kepada si penipu. ${ }^{12}$

Dari pengertian tersebut dapat disimpulkan bahwa frand atau kecurangan adalah berbagai macam carakecerdikan manusia yang direncanakan dan dilakukan secara individual maupun berkelompok untuk memperoleh manfaat atau keuntungan dari pihak lain dengan cara yang tidak benarsehingga menimbulkan kerugian bagi pihak lain. Dengan kata lain, kecurangan dalah penipuan yang disengaja, yang dimaksudkan untuk mengambil aset atau hak orang lain.

\footnotetext{
${ }^{11}$ Tommie W. Singleton dan Aaron J, Fraud Auditing and Forensic Accounting, (John Wiley \& Sons, Inc., 2010), h. 5.

${ }^{12}$ G. Jack Bologna, Robert J. Lindquist dan Joseph T. Wells., Frand Auditing and Forensic Accounting: New Tolls and Techniques, (John Wiley \& Sons, Inc., 1995), h.4.
} 
Suatu kegiatan dapat dikategorikan sebagai suatu kecurangan jika adanya keuntungan bagi diri sendiri atau kelompok, merugikan pihak lain, dan cara yang tidak benar, Ilegal atau perbuatan melawan hukum. ${ }^{13}$

Kecurangan korporasi umumnya berasal dari dua arah yaitu kecurangan dari internal dan kecurangan dari eksternal.Kecurangan internal adalah kecurangan yang berasal dari pihak dalam perusahaan itu sendiri. Kecurangan dari internal contohnya seperti korupsi, penyajian palsu, rekayasa laporan keuangan, laporan keuangan ganda, menutupi atau menyamarkan penggelapan uang, ketidakcakapan dalam penghitungan, pencurian atau penggunaan aktiva organisasi yang tidak tepat oleh para pegawai dan manajemen untuk kepentingan pribadi atau kelompok serta penggunaan dana yang tidak sesuai dengan peruntukkannya. ${ }^{14}$ Sedangkan kecurangan eksternal adalah kecurangan yang berasal dari pihak luar perusahaan.Seperti melalui penyuapan, peninggian nilai faktur (overbilling), adanya faktur ganda (double billing) serta penipuan kualitas seperti transaksi barang yang tidak sesuai dengan perjanjian yang telah disepakati misalkan rendahnya kualitas mutu produk dan jasa. ${ }^{15}$

Jika dilihat dari sudut pandang akuntansi, maka frand atau kecurangan adalah suatu kekeliruan atau penggambaran yang salah dari fakta material dalam penyajian fakta pembukuan dan akhirnya dalam laporan keuangan. ${ }^{16}$ Kecurangan akuntansi ini dibagi menjadi dua kelompok utama, yaitu kecurangan laporan dan kecurangan transaksi.Kecurangan laporan mencakup kesalahan pelaporan yang disengaja sehingga terlihat kondisi keuangan perusahaan lebih baik dari pada kenyataannya dan akhirnya menipu para pemegang saham, investor dan kreditur. Kecurangan laporan yang paling banyak terjadi adalah pendapatan dan persediaan yang "ditinggikan" atau biasa disebut pola Income Maximization, perataan laba (Income Smoothing), serta pengaturan laba (Earnings Management). ${ }^{17}$ Adapun Kecurangan transaksi biasanya dilakukan untuk mempermudah pencurian atau konversi aset entitas atau perusahaan menjadi aset pribadi.Kecurangan transaksi contohnya adalah pengalihan aset perusahaan menjadi aset milik pribadi dan hutang fiktif.

\footnotetext{
${ }^{13}$ Theodorus M Tuanakotta, Akuntansi Forensik dan Audit Investigatif, (Jakarta: Salemba Empat, 2010), h. 194.

${ }^{14}$ Amin Widjaja, Forensic \& Investigative Accounting: Pendekatan Kasus, h. 3.

${ }^{15}$ Tommie W. Singleton dan Aaron J, Fraud Auditing and Forensic Accounting,h. 59.

${ }^{16}$ Amin Widjaja, Forensic \& Investigative Accounting: Pendekatan Kasus, h.7.

${ }^{17}$ Dedhy Sulistiawan, Yeni Januarsi dan Liza Alvia, Creative Accounting: Mengungkap Manajemen Laba dan Skandal Akuntansi, h. 42.
} 
Profil Kecurangan dapat dilakukan siapapun dan pihak manapun.Seperti karyawan, manajemen, ataupun investor. Contoh kecurangan langsung yang dilakukan karyawan adalah pengambilan uang kas, persediaan, dan peralatan perusahaan serta pengambilan peralatan, perlengkapan inventaris kantor. Sedangkan kecurangan yang melibatkan pihak ketiga misalnya adalahsuap/kickback/bribe. ${ }^{18}$ Kecurangan yang dilakukan oleh manajemen misalnya adalah membuat laba bersih terlihat lebih ringgi, atau sebaliknya memperendah nilai rugi bersih perusahaan, atau menyembunyikan kerugian, investasi fiktif serta rekayasa laporan keuangan. ${ }^{19}$

\section{Fraud Tree (Jenis-Jenis Fraud).}

Secara skematis, Association of Certified Frand Examiners (ACFE) menggambarkan fraud atau kecurangan dalam bentuk frand tree atau pohon frand. Skema ini menggambarkan cabang-cabang fraud dalam hubungan kerja beserta ranting dan anak rantingnya masing-masing. Adapun fraud tree atau pohon fraud dalam occupational fraud (hubungan kerja) ini dapat dilihat pada bagan sebagaimana berikut di bawah ini:

${ }^{18}$ Theodorus M Tuanakotta, Akuntansi Forensik dan Audit Investigatif, h. 198

${ }^{19}$ Emil Bachtiar, Kasus-Kasus Etika Bisnis dan Profesi, (Jakarta: Salemba Empat, 2012), h. 1-6. 
Bagan 1.

Fraud Tree

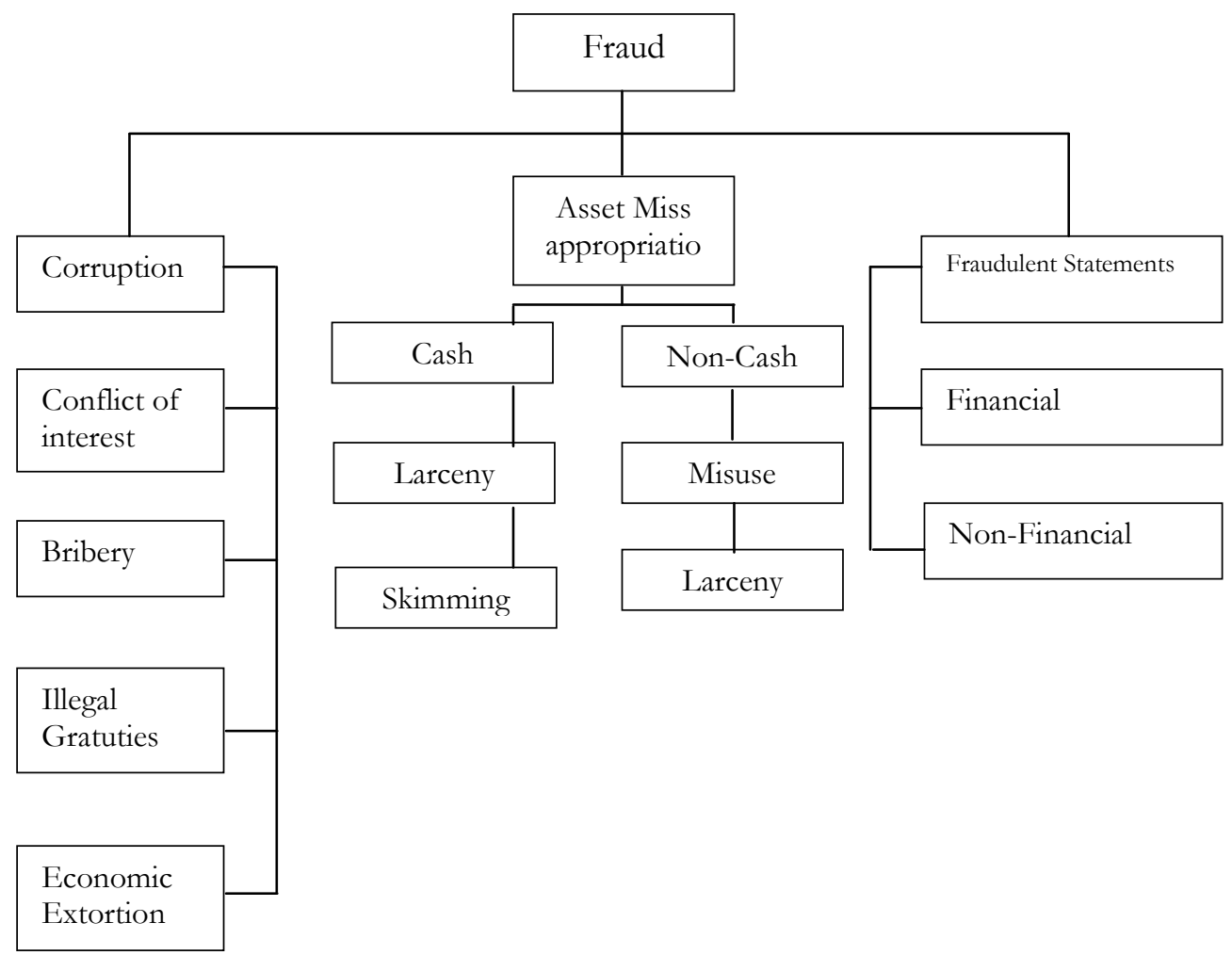

Sumber: Association of Certified Fraud Examiners, 2008 Report to the Nation on Occupational Frand and Abuse. 
Berdasarkan pada frand tree di atas, maka dapat disimpulkan bahwa secara umumfrand atau kecurangan terbagi dalam tigayaitu: ${ }^{20}$

a. Korupsi.

Korupsi ini mencakup beberapa hal seperti konflik kepentingan rekan atau keluarga dalam proyek, penyuapan, pengambilan dana secara paksa, permainan dalam tender dan graftifikasi terselubung.

b. Pengambilan aset secara ilegal

Pengambilan aset secara ilegal ini maksudnya adalah pengambilan aset secara tidak sah atau melawan hukum. Adapun pengambilan aset secara illegal ini mencakup 3 hal yaitu:

- Skimming atau penjarahan, yaitu uang dijarah sebelum masuk kas perusahaan. Dengan kata lain, dana diambil sebelum adanya pembukuan.

- Lapping atau pencurian, yaitu uang dijarah sesudah masuk kas perusahaan. Contohnya adalah pembebanan tagihan yang tidak sesuai dengan kenyataannya, pembayaran biaya-biaya yang tidak logis serta pemalsuan cek.

- Kitting atau penggelapan dana, yakni adanya bentuk penggelembungan dana, atau adanya dana mengambang (free money). ${ }^{21}$

c. Kecurangan laporan keuangan

Ini berupa salah saji material dan data keuangan palsu.Salah saji material adalah kesalahan hitung dan angka dalam laporan keuangan.Seperti menyajikan aset atau pendapatan lebih tinggi dari yang sebenarnya atau sebaliknya.Sedangkan data keuangan palsu adalah rekaan data keuangan.

\section{Fraud Triangle (Motif-Motif Fraud).}

Frand Triangle atau segi tiga Frand adalah sebuah skema yang menggambarkan tentang motif-motif atau penyebab terjadinya suatu tindakan kecurangan.Segitiga Fraud ini merupakan model yang menghubungkan antara

${ }^{20}$ Theodorus M Tuanakotta, Akuntansi Forensik dan Audit Investigatif, hlm. 195-204.

${ }^{21}$ Free Money atau Dana mengambang adalah dana yang ditarik dari suatu bank, kemudian disetorkan ke bank lainnya, ditarik lagi dan disetorkan lagi, begitu dan begitu seterusnya. Bergerak dan terus menerus bergerak sehingga tidak berhenti pada satu bank saja. Lihat Amin Widjaja, Forensic \& Investigative Accounting: Pendekatan Kasus,hlm. 10. 
tiga kelompok besar penyebab terjadinya suatu kecurangan. ${ }^{22}$ Titik pertama Segitiga Fraud ini adalahPressure, atau permulaan dari adanya suatu tekanan yang menghimpitnya. Seperti kebutuhan akan adanya uang untuk keperluan yang mendesak. Titik kedua adalah Perceived Opportunity, atau tersedianya peluang bagi pelaku kecurangan, seperti adanya kesempatan melakukan tindakan kecurangan tanpa diketahui orang lain serta kurangnya pengawasan oleh atasan. Terakhir, titik ketiga adalah Rationalization, atau rasionalisasi, yaitu mencari pembenaran sebelum melakukan suatu tindak kejahatan. Adapun Frand Triangle atau segi tiga Frand) ini dapat dilihat pada bagan sebagaimana berikut di bawah ini:

\section{Bagan 2.}

Segitiga Fraud

PERCEIVED OPPORTUNITY

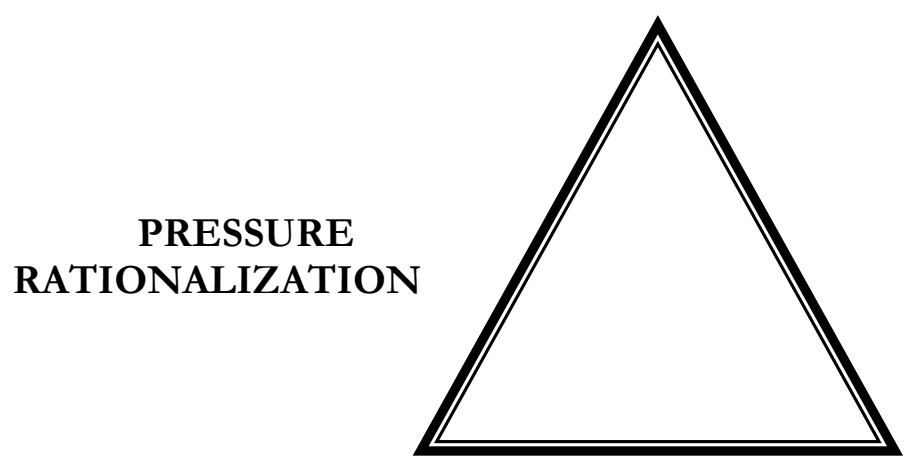

Selain motif-motif Frand yang digambarkan dalam segi tiga Fraud di atas, ada pula terdapat beberapa penyebab terjadinya Fraud atau kecurangan lainnya yaitu, seperti karena motif ekonomi, tekanan keuangan, serta tekanan karena pekerjaan. ${ }^{23}$ Motif ekonomi menandakan bahwa pelaku mempunyai tujuan utama berupa kebutuhan atau keinginan untuk memperoleh keuntungan finansial dari kecurangan tersebut, yaitu berupa uang atau sesuatu yang dapat ditukar dengan uang. ${ }^{24}$ Dalam hal ini, biasanya kecurangan terjadi disebabkan

${ }^{22}$ Lihat dalam Association of Certified Fraud Examiners, Fraud Examiners Manual, 2006 edition dan Theodorus M Tuanakotta, Akuntansi Forensik dan Audit Investigatif, hlm. 207.

${ }^{23}$ Karni Soejono, Auditing: Audit Khusus dan Audit Forensik dalam Praktek, (Jakarta: Lembaga Penerbitan FE UI, 2000), hlm. 27.

${ }^{24}$ Amin Widjaja, Forensic \& Investigative Accounting: Pendekatan Kasus, hlm.177. 
karena adanya dorongan untuk memiliki harta lebih seperti gaya hidup mewah, demi harga diri atau agar lebih dipandang dimasyarakat. Atau jumlah penghasilan gaji minim padahal kebutuhan hidup yang harus dipenuhi banyak.Ada pula yang disebabkan tekanan pekerjaan seperti adanya tekanan pekerjaan dari pihak ketiga.

Motif kecurangan lainnya adalah egosentris, ideologis dan psykhotis. ${ }^{25}$ Motif egosentris berasal dari fakta bahwa sang penipu lebih pintar dan lebih cerdik dari pada orang lain, dalam arti dia dapat memanipulasi dan merekayasa hasil pekerjaannya seperti memanipulasi buku besar tanpa diketahui atau dideteksi.

Sedangkan Motif ideologis muncul karena pelaku tidak puas akan sesuatu sehingga menimbulkan motif eksploitasi terhadap lainnya. Atau berupa protes yang kuat akansesuatu, seperti pemrotes perpajakan misalkan dengan cara memanipulasi hitungan pajak sehingga pajak menjadi nihil atau sebaliknya.

Motif Psychotis, adalah Egosentris dalam bentuk ekstrim, sehingga terkesan cuek atau acuh tak acuh pada keadaan.Contohnya seperti gangguan mental klaptomania, atau melakukan kejahatan mereka diluar kewajiban atau obsesi.

Selain empat motif penyebab terjadinya Fraud atau kecurangan di atas, ada pula motif lain yang dapat menyebabkan terjadinya suatu Frand atau kecurangan, yaitu penyebab yang berasal dari lingkungan internal (dalam) perusahaan dan lingkungan eksternal (luar) perusahaan. ${ }^{26}$

a. Motif Fraud dari lingkungan internal perusahaan

Pengaruh internal perusahaan yang dapat menambah motif terjadinya Fraud atau kecurangan mencakup berbagai hal:

- Lingkungan kerja yang tidak mendukung

- Sistem yang tidak memadai

- Sistem penghargaan yang kurang

- Kurangnya tingkat kepercayaan interpersonal

- Kurangnya tingkat etika

- Tingkat stress yang tinggi

${ }^{25}$ G. Jack Bologna, Robert J. Lindquist dan Joseph T. Wells. Fraud Auditing and Forensic Accounting: New Tolls and Techniques,hlm. 17.

${ }^{26}$ Teori tentang Motif-Motif penyebab terjadinya suatu tindakan kecurangan atau Frand ini lebih dikenal dengan konsep MOMM, yaitu suatu akronim untuk Motivasi, Kesempatan, Alat dan Metode (Motivation, Opportunity, Means, and Method). 
- Tuntutan pekerjaan

- Kompetisi yang tidak sehat

- Tidak berfungsinya tingkat Pengendalian Internal

- Tidak berfungsinya Manajemen Risiko Perusahaan

b. Motif Fraud dari lingkungan eksternal perusahaan

Sedangkan pengaruh lain yang berasal dari lingkungan eksternal perusahaan yang dapat menambah motif terjadinya suatu Frand atau kecurangan adalah:

- Kondisi industri yang penuh kompetisi

\section{Akuntansi Forensik}

- Kondisi ekonomi yang tidak stabil dan tidak mendukung

Akuntansi Forensik merupakan cabang akuntansi yang relatif baru yang secara umum dapat dipahami sebagai subset disiplin akuntansi dalam pemeriksaan keuangan. Disiplin ini sangat dibutuhkan khususnya terkait dengan tindakan-tindakan fraud bidang keuangan yang dilakukan secara samar dan canggih baik di perusahaan maupun di lembaga keuangan dan perbankan.

Istilah "Akuntansi Forensik" pertama sekali diciptakan Seorang Rekan di Firma Akunting di New York yang bernama Maurice E. Peloubet Pada tahun $1946 .{ }^{27}$ Akuntansi Forensik terbentuk dari banyak kolaborasi antara Akuntansi dan sistem hukum.Pengacara menggunakan akuntansi forensik untuk menemukan bukti dalam kasus kerah putih yang tidak dapat mereka peroleh. Bukti ini akan membantu memenangkan banyak kasus.

Akuntansi forensik sebenarnya telah dipraktekkan di Indonesia.Praktek ini tumbuh pesat, tak lama setelah terjadi krisis keuangan tahun $1977 .^{28}$ Akuntansi forensik dilaksanakan oleh berbagai lembaga seperti Badan Pemeriksa Keuangan (BPK), Komisi Pemberantasan Korupsi (KPK), Pusat Pelaporan dan Analisis Transaksi Keuangan (PPATK), Badan Pengawasan Keuangan dan Pembangunan (BPKP), Bank Dunia (untuk proyek-proyek pinjamannya), dan kantor-kantor akuntan publik (KAP) di Indonesia.

Istilah akuntansi forensik di Indonesia baru terlihat suksesnya setelah keberhasilan PricewaterhouseCoopers ( $\mathrm{PwC}$ ) dalam membongkar kasus Bank Bali. ${ }^{29} \mathrm{PwC}$ dengan software khususnya mampu menunjukkan arus dana yang

\footnotetext{
${ }^{27}$ Theodorus M Tuanakotta, Akuntansi Forensik dan Audit Investigatif, h. 15.

${ }^{28}$ Lihat Amin Widjaja, Forensic \& Investigative Accounting: Pendekatan Kasus,hlm. 511.

${ }^{29}$ Theodorus M Tuanakotta,Menghitung Kerugian Kenangan Negara dalam Tindak Pidana Korupsi, (Jakarta: Salemba Empat, 2010), hlm. 4.
} 
rumit berbentuk seperi diagram cahaya yang mencuat dari matahari (Sunburst). Kemudian $\mathrm{PwC}$ meringkasnya menjadi arus dana dari orang-orang tertentu. Metode yang digunakan dalam audit tersebut adalah Follow The Money atau mengikuti aliran uang hasil korupsi Bank Bali dan In Depth Interviewatau interview secara mendalam yang kemudian mengarahkan kepada para pejabat dan pengusaha yang terlibat dalam kasus ini tersebut.

Masih pada tahun yang sama, Pusat Pelaporan dan Analisis Transaksi Keuangan (PPATK) mampu memecahkan kasus BNI, yang membuktikan kepada pengadilan bahwa Adrian Waworuntu terlibat dalam penggelapan L/C BNI senilai Rp 1.3 Triliun, dengan menggunakan Metode Follow The Money yang mirip dengan metode $\mathrm{PwC}$ yang digunakan dalam kasus Bank Bali. Padahal sebelum keterangan para ahli PPATK, Adrian Waworuntu selalu berhasil meyakinkan bahwa dirinya sama sekali tidak terlibat. ${ }^{30}$

Keberhasilan-keberhasilan di atas semakin membuat akuntansi forensik berkembang pesat.Bahkan sekarang akuntansi forensik dimasukkan dalam kurikulum pendidikan akuntansi di berbagai tingkat perguruan tinggi di Indonesia.Diikuti pula dengan banyaknya dibuka program-program pendidikan khusus Akuntansi forensik ${ }^{31}$ Dengan begitu, kalangan akademisi bisa lebih tanggap terhadap kasus-kasus kecurangan akuntansi dan laporan keuangan yang kerap terjadi di negara ini.Diharapkan pula setelah mempelajari tentang akuntansi forensik ini dapat memberikan sumbangsih pikiran untuk keberlangsungan dan pengembangan akuntansi forensik di Indonesia.

Forensik, jika kita mendengar istilah ini, maka asumsi awal kita adalah ahli patologi yang memeriksa jenazah untuk menentukan penyebab dan waktu kematian.Tidak salah, karena memang dalam ilmu kedokteran, forensik berarti ilmu bedah yang berkaitan dengan penentuan identitas mayat. ${ }^{32}$ Lalu bagaimana dengan akuntansi forensik?, apakah sebenarnya akuntansi forensik itu?.

Istilah akuntansi forensik merupakan terjemahan dari Forensic Accounting.Akuntansi forensik adalah ilmu yang relatif baru.Bidang akuntansi

\footnotetext{
${ }^{30}$ Pusat Pelaporan dan Analisis Transaksi Keuangan, "Indonesia Melawan Praktek Pencucian Uang, Jakarta: Maret 2003.

${ }^{31}$ Representasi dari upaya untuk mengembangkan bidang ilmu akuntansi forensik adalah dengan dibukanya Pusat studi Akuntansi Forensik yang berada di bawah Program Studi Akuntansi Universitas Islam Indonesia dan Program baru Fakultas Ekonomi Universitas Trunojoyo yaitu program Magister Akuntansi (M.Ak) dengan kurikulum yang dirancang khusus berfokus pada Akuntansi Forensik.

${ }^{32}$ Departemen Pendidikan dan Kebudayaan, Kamus Besar Bahasa Indonesia, cet. II (Jakarta: Balai Pustaka, 1990), hlm. 241.
} 
yang satu ini mungkin jarang sekali kita dengar.Bahkan mahasiswa jurusan akuntansi saja belum tentu mengerti sepenuhnya apa itu akuntansi forensik.

Ada beberapa macam pengertianakuntansi forensik, antara lain sebagai berikut:

a. Menurut Theodorus M Tuanakotta, akuntansi forensik adalah penerapan sistem akuntansi dalam bidang hukum terutama pada permasalahan-permasalahan kecurangan atau fraud. ${ }^{33}$

b. Sedangkan menurut Larry Crumbley, secara sederhana dapat dikatakan bahwa akuntansi forensik adalah sistem akuntansi pemeriksaan yang akurat untuk tujuan hukum. ${ }^{34}$

c. Menurut Jack Bologna, akuntansi forensik dapat diartikan sebagai akuntansi yang berkenaan dengan pengadilan atau berkenaan dengan penerapan pengetahuan ilmiah akuntansi pada masalah hukum. ${ }^{35}$

Berdasarkan keterangan diatas dapat disimpulkan bahwa Akuntansi forensik adalah penggunaan keahlian akuntansi yang dipadukan dengan kemampuan investigasi untuk memecahkan suatu masalah atau dugaan fraud.Akuntansi forensik pada dasarnya adalah perpaduan antara bidang akuntansi dan hukum.Kedua disiplin ilmu tersebut saling mengisi satu sama lain. Oleh karena itulah akuntasi forensik bisa diartikan sebagai penggunaaan ilmu akuntansi untuk kepentingan hukum.

Akuntansi forensik ini bertujuan untuk menerjemahkan transaksi keuangan yang kompleks dari data, angka ke dalam bentuk yang dapat dimengerti secara umum. Serta memahami apa yang ada di balik laporan keuangan. Hal ini tentu saja, dimaksudkan agar segala sesuatu dapat dilakukan pendeteksian sejak dini, sehingga bisa segera diketahui ada yang tidak beres dalam data-data keuangan yang disajikan.

Misalkan dalam suatu proses akuntansi, jumlah akun tertentu dapat dinyatakan sebagai sesuatu yang mencurigakan, jika berlebihan atau kurang dari perkiraan dan kisaran normal, atau tanda lain yang menyebabkan pertanyaan secara akuntansi. Maka akun tersebut akan ditandai untuk dipelajari dan dianalisis lebih lanjut. Hal di atas akan membuat akuntan bertanya apa yang menyebabkan terjadi kejadian seperti itu. Beberapa akuntan forensik menyebut

${ }^{33}$ Theodorus M Tuanakotta, Akuntansi Forensik, dan Audit Investigatif, (Jakarta: Salemba Empat, 2010), hlm. 4.

${ }^{34}$ Larry D. Crumbley, Forensic and Investigative Accounting, hlm. 5.

${ }^{35} \mathrm{G}$. Jack Bologna, Robert J. Lindquist dan Joseph T. Wells. Fraud Auditing and Forensic Accounting: New Tolls and Techniques,hlm. 5. 
monitor seperti itu sebagai "Red Flags" (sinyal kecurangan). Dengan kata lain, Angka-angka tersebut mungkin dapat membuktikan kecurangan tertentu yang disembunyikan atau disamarkan, atau bahkan ditutup-tutupi.

Ada beberapa perbedaan antara Akuntansi Umum dan Akuntansi Forensik, yaitu dari segi waktu, akuntansi forensik kasusistis sedangkan akuntansi umum dilakukan secara regular.Lingkup akuntansi forensik spesifik, bukan laporan keuangan secara umum.Tujuan akuntansi forensik membuktikan kecurangan, bukan memberikan opini, serta teknik yang dipakai adalah perpaduan antara teknik akuntansi dan hukum.

\section{Segi Tiga Akuntansi Forensik}

Akuntansi Forensik dapat dilihat dengan berbagai cara dari mulai dari yang paling sederhana sampai yang paling rumit. Salah satu cara termudah adalah menggunakan skema Segitiga Akuntansi Forensik.

Segitiga Akuntansi Forensik merupakan model yang mengaitkan disiplin akuntansi, hukum dan auditing. Segitiga Akuntansi Forensik menghubungkan tiga aspek yaitu kerugian, perbuatan melawan hukum dan hubungan kausalitas. ${ }^{36}$ Titik pertama Segitiga Akuntansi Forensik adalah kerugian, titik kedua adalah perbuatan melawan hukum dan titik ketiga adalah hubungan kausalitas antara kerugian dan perbuatan melawan hukum.Masingmasing ketiga aspek tersebut saling berhubungan erat tanpa bisa dipisahkan.Kerugian timbul akibat adanya perbuatan melawan hukum.Tanpa perbuatan melawan hukum, tidak ada yang dapat dituntut untuk dapat mengganti kerugian.Serta adanya keterkaitan antara kerugian dan unsur perbuatan melawan hukum.

36 Theodorus M Tuanakotta, Akuntansi Forensik dan Audit Investigatif, hlm. 22. Lihat pula . Jack Bologna, Robert J. Lindquist dan Joseph T. Wells. Frand Auditing and Forensic Accounting: New Tolls and Techniques,hlm. 25. 


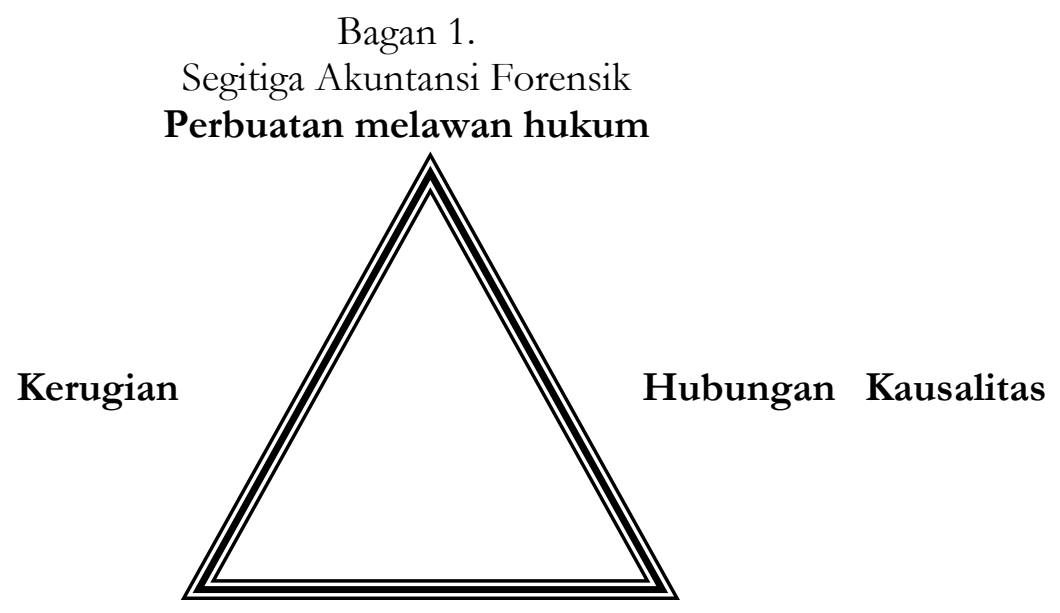

\section{FOSA dan COSA}

Akuntansi Forensik secara sistem terbagi dua tipe yaitu: ${ }^{37}$

a) FOSA atau Frand Oriented system audit, adalah akuntansi forensik yang menangani masalah-masalah fraud dalam 2 fokus kajian yaitu Pengambilan asset secara illegal berupa Skimming (Penjarahan), Lapping (Pencurian) Kitting (Penggelapan dana), serta Kecurangan laporan keuangan berupa salah saji material dan data keuangan palsu. Dengan demikian untuk mengidentifikasi fraud secara umum, digunakan FOSA.

b) COSA atau Corruption Oriented system audit adalah akuntansi forensik yang menangani masalah fraud dalam fokus kajian yaitu Korupsi. Jadi COSA digunakan untuk identifikasi fraud secara spesifik yaitu korupsi.

\section{Standar Akuntansi Forensik.}

Adapun standar akuntansi Forensik ada empat macam yaitu: ${ }^{38}$

a. Independensi; akuntan forensik harus independen dalam melaksanakan tugasnya, bertangggung jawab dan objektif atau tidak memihak dalam melaksanakan telaahan akuntansi forensiknya.

b. Kemahiran Profesional; akuntansi forensik harus dilaksanakan dengan kemahiran dan kehati-hatian professional.

c. Lingkup Penugasan; akuntan harus memahami tugasnya dengan baik,

${ }^{37}$ Theodorus M Tuanakotta, Akuntansi Forensike dan Audit Investigatif, hlm. 24.

${ }^{38}$ Ibid., hlm. 122-123. 
mengkajinya dengan teliti dan melaporkannya dalam kontrak.

d. Pelaksanaan Tugas Telaahan; akuntan harus memahami permasalahan dengan baik, seperti rumusan masalah, perencanaan dan pengumpulan bukti dan evaluasinya, sampai pada tahap komunikasi hasil penugasan berupa laporan akhir yang berisi fakta dan kesimpulan.

\section{Audit Investigatif.}

Kita harus membedakan "investigasi" yang merupakan istilah hukum dari "audit investigatif" yang merupakan istilah akuntansi forensik.Meskipun kedua istilah tersebut dibedakan, diantara keduanya ada keterkaitan yaitu aturan formil yaitu berdasarkan Kitab Undang-Undang Hukum Acara Pidana atau KUHAP.

Audit Investigatif secara sederhana dapat didefinisikan sebagai suatu upaya pembuktian atas suatu kesalahan sesuai dengan ketentuan hukum yang berlaku. ${ }^{39}$ Istilah Audit Investigatif menegaskan bahwa yang dilakukan adalah suatu audit.Audit umum atau audit keuangan yang bertujuan untuk pemberian pendapat auditor independen mengenai kewajaran penyajian laporan keuangan. Oleh karena itulah, audit ini juga disebut dengan opinion audit. Audit Investigatif diarahkan kepada pembuktian ada tidaknya fraud dan perbuatan melawan hukum lainnya.

Setiap audit investigatif dimulai dengan keinginan bahwa kasus ini berakhir dengan litigasi. Suatu investigasi dimulai apabila ada dasar yang layak untuk dilakukan suatu pemeriksaan, yang dalam audit investigasi disebut dengan prediksi.Prediksi adalah dasar untuk memulai investigasi.

Fraud Examiners Manual menjelaskan bahwa prediksi adalah keseluruhan dari peristiwa, keadaan pada saat peristiwa itu, dan segala hal yang terkait atau berkaitan yang membawa seseorang yang cukup terlatih dan berpengalaman dengan kehati-hatian yang memadai, kepada kesimpulan bahwa fraud tersebut telah, sedang atau akan berlangsung. Investigasi atau pemeriksaan fraud tidak bisa dilaksanakan tanpa adanya prediksi yang tepat. ${ }^{40}$

Dengan dasar prediksi ini, investigator akan memeriksa mengenai halhal yang relevan dengan kasus yang ditelitinya, lalu menguji prediksinya dan kemudian ia pun membangun teori Fraud. Audit Investigatif dengan pendekatan teori fraud, meliputi langkah-langkah sebagai berikut:

a. Analisis data yang tersedia.

\footnotetext{
${ }^{39}$ Theodorus M Tuanakotta, Akuntansi Forensik dan Audit Investigatif, hlm. 321.

${ }^{40}$ Lihat dalam Association of Certified Fraud Examiners, Frand Examiners Manual, 2006 edition dan Theodorus M Tuanakotta, Akuntansi Forensik dan Audit Investigatif, hlm. 331.
} 
b. Ciptakan atau kembangkna berdasarkan analisis diatas

c. Uji atau tes hipotesis tersebut

d. Ubah dan simpulkan hipotesis berdasarkan hasil pengujian.

Kalau kita bisa menjawab, kelima $\mathrm{W}$ dan satu $\mathrm{H}$ (what, why, when, where, who, and how) atau apa, mengapa, kapan, dimana, siapa, dan bagaimana fraud tersebut, maka ia telah mempunyai teori Frand. Namun khusus untuk audit investigatif, ada satu hal lagi yang harus dijawab yaitu satu $\mathrm{H}$, yaitu how much atau seberapa banyak. Sehingga dalam audit investigatif kita mempunyai rumus 5W 2H. (what, why, when, where, who, how and how much).

\section{Aksioma dalam Audit Investigatif.}

Dalam pandangan para filsuf yunani, aksioma adalah klaim atau pernyataan yang dapat dianggap benar, tanpa pembuktian lebih lanjut. Tradisi ini diteruskan dala logika, bahkan sampai pada apa yang kita sebut dengan ilmu-ilmu eksakta.

Aksioma atau postulate adalah penyataan yang tidak dibuktikan atau diragukan lagi, dan dianggap sudah jelas dengan sendirinya. Kebenaran dari proposisi ini tidak dipertanyakan lagi (taken for granted). Aksioma merupakan titik tolak untuk menarik kesimpulan tentang suatu kebenaran yang harus disimpulkan (melakukan pembentukan teori).Meskipun Aksioma ini tidak memerlukan pembuktian kebenarannya.Namun, jangan remehkan "kegamblangannya". Karena terkadang investigator berpengalaman pun sering kali menghadapi berbagai masalah ketika ia mengabaikan aksioma-aksioma tersebut.

Association of Certified Frand Examiners (ACFE) menyebut tiga aksioma dalam melakukan audit investigasi atau pemeriksaan fraud. Ketiga istilah tersebut oleh ACFE disebut dengan frand axioms atau aksioma fraud, yang terdiri dari: ${ }^{41}$

a. Frand is hidden atau fraud selalu tersembunyi.

Berbeda dengan kejahatan lain, sifat perbuatan fraud selalu tersembunyi. Metode atau modus operandinya selalu mengandung tipuan untuk menyembunyikan sedang berlangsungnya suatu fraud.Metode menyembunyikan frand sangat banyak.Pelaku frand sangat kreatif dalam mencari celah-celah untuk menyembunyikan fraud nya.Seperti direksi Bank memfasililtasi pelanggannya dengan

${ }^{41}$ Lihat Amin Widjaja, Forensic \& Investigative Accounting: Pendekatan Kasus, hlm.55. lihat pula Theodorus M Tuanakotta, Akuntansi Forensik dan Audit Investigatif, hlm. 322-324. 
membuka L/C fiktif atau memberikan kredit bodong yang segera menjadi NPL (Non Performing Loan).

b. Reverse proof atau pembuktian secara terbalik.

Maksud dari pembuktian terbalik ini adalah bahwa pemeriksaan frand harus didekati dari dua arah.Untuk membuktikan bahwa frand terjadi, pembuktian harus dilakukan dengan upaya membuktikan bahwa fraud tidak terjadi.Dan begitu pula sebaliknya.Dalam membuktikan bahwa fraud tidak terjadi, pembuktian harus meliputi upaya membuktikan bahwa fraud memang terjadi.

c. Existence of frand atau penetapan fraud oleh pengadilan.

Aksioma ini ingin mengatakan secara sederhana bahwa hanya pengadilan yang berhak menetapkan tentang status hukum fraud.Dalam upaya menyelidiki ada tidaknya fraud, investigator membuat dugaan mengenai seseorang bersalah (guilty) atau tidak bersalah (innocent). Hanya pengadilan yang mempunyai kewenangan menetapkan fraud itu terjadi atau tidak.Sehingga seseorang tersebut pada akhirnya menerima vonisnya.

\section{Standar Audit Investigatif.}

Secara sederhana, standar adalah ukuran mutu.Dengan standar ini, pihak yang diaudit (auditee), pihak yang memakai laporan audit, dan pihak-pihak lain dapat mengukur mutu kerja auditor.Seperti Akuntan publik memiliki Standar Profesi Akuntan Publik (SPAP).SPAP ini memuat standar audit, atestesi dan pengendalian mutu. Hal yang sama juga terjadi pada para investigator dan forensic accountant.

Menurut K.H. Spencer Pickett dan Jennifer Pickett, ada beberapa standar audit investigatif dalam pemeriksaan Fraud, yaitu sebagai berikut: ${ }^{42}$

a. Seluruh investigasi harus dilakukan berdasarkan pada praktekpraktek audit yang diakui sesuai standar.

b. Pengumpulan bukti, barang bukti dan alat bukti dengan prinsip kehati-hatian.

c. Memastikan seluruh dokumentasi dalam keadaan aman, terlindungi dan diindeks dan tersedianya jejak audit.

d. Memastikan bahwa para investigator mengerti dan menghormati hak sesama, seperti asas praduga tak bersalah dan mengormati

${ }^{42}$ K.H. Spencer Pickett dan Jennifer Pickett, Financial Crime Investigation dan Control, hlm. 140. 
kebebasan seseorang.

e. Beban pembuktian harus melampaui keraguan yang layak, seperti sedikitnya 2 alat bukti yang meyakinkan.

f. Menguasai seluruh cakupan substansi investigasi dan targetnya sesuai waktu.

g. Mendokumentasikan seluruh tahapan dalam proses investigasi atau pemeriksaan Fraud, termasuk perencanaan, pengumpulan bukti dan barang bukti, wawancara dan kontak dengan pihak ketiga, pengamanan mengenai hal-hal yang bersifat rahasia, mengikuti protokol dan sesuai prosedur, arsip dan penyelenggaraan pencatatan, melibatkan hukum, kewajiban hokum dan persyaratan pelaporan lainnya.

\section{Teknik-Teknik Audit Investigatif.}

Secara umum ada sembilan teknik audit investigatif yang biasa digunakan untuk mengungkap adanya tindak kecurangan atau Fraud, yaitu: ${ }^{43}$

1) Penggunaan teknik-teknik pemeriksaan laporan keuangan.

Pemeriksaan ini berfungsi untuk menilai kewajaran penyajian laporan keuangan.Ada tujuh langkah pemeriksaan laporan keuangan ini, yaitu: ${ }^{44}$

a. Memeriksa Fisik dan Mengamati

Memeriksa fisik lazimnya diartikan sebagai penghitungan uang tunai, surat berharga, persediaan asset, dan barang berwujud lainnya. Sedangkan mengamati adalah menggunakan alat indera untuk mengetahui atau memahami sesuatu tentang lingkungan keuangan.

b. Meminta Informasi dan Konfirmasi.

Meminta informasi kepada perusahaan baik secara lisan maupun tertulis. Ini harus diperkuat atau dikolaborasikan dengan informasi dari sumber lain. Tujuannya adalah untuk menegaskan kebenaran atau ketidakbenaran informasi.Ini umumnya untuk memastikan saldo utang-piutang.

c. Memeriksa Dokumen.

Dokumen harus diperiksa guna memperoleh pemahaman tentang nilai bukti potensial kasus.Dokumen mempunyai definisi yang luas,

\footnotetext{
${ }^{43}$ Theodorus M Tuanakotta, Akuntansi Forensik dan Audit Investigatif, hlm. 295-296.
}

${ }^{44}$ Ibid., hlm. 350-359. 
termasuk informasi keuangan yang diolah dan disimpan secara elektronis (digital).

\section{d. Review Analitikal}

Review analitikal dapat disajikan melalui beberapa teknik, yaitu:

1) Membandingkan anggaran dengan realisasi

Membandingkan antara data anggaran dengan realisasi bukti fisiknya.

2) Analisis vertikal dan horizontal.

Ini merupakan teknik analisis laporan keuangan.Analisis vertikal adalah Analisis Common-Size yaitu teknik analisis untuk mengetahui proporsi dari setiap komponen dalam laporan keuangan terhadap besaran totalnya dalam satuan persen. ${ }^{45}$ Selain itu ada pula analisis Rasioyang merupakan teknik analisis laporan keuangan yang digambarkan dalam bentuk rasio keuangan. Rasio-rasio keuangan ada lima macam yaitu Rasio Likuiditas, Solvabilitas, Aktivitas, Profitabilitas dan Pasar. Sedangkan analisis horizontal adalah teknik analisis Cross-Section. ${ }^{46}$ Analisis Cross-Section juga sering disebut dengan analisis komparasi atau analisis perbandingan.Selain analisis Cross-Section, terdapat pula Analisis Sumber dan Penggunaan Dana, yang dapat diartikan sebagai Analisis yang bertujuan untuk melihat aliran kas (cashflow) dan setara kas) pada periode tertentu.

3) Analisis Regresi dan Trend

Merupakan teknik analisis laporan keuangan yang menggambarkan kecendrungan perubahan suatu pos laporan keuangan selama beberapa periode. ${ }^{47}$ Analisis trend dapat memberikan informasi tingkat pertumbuhan masing-masing pos laporan keuangan dari tahun ke tahun dan gambaran apakah kinerja bank naik, turun atau konstan.

4) Membandingkan data keuangan atau komparasi. ${ }^{48}$

Disebut komparasi karena dalam hal ini teknik yang digunakan adalah membandingkan angka-angka keuangan dengan standar

\footnotetext{
${ }^{45}$ Mamduh M. Hanafi dan Abdul Halim, Analisis Laporan Kenangan (Yogyakarta : UPP STIM YKPN, Agustus 2007), hlm. 70.

${ }^{46}$ Harnanto, Analisis Laporan Keuangan (Yogyakarta: BPFE, 1987), hlm. 26.

${ }^{47}$ Sofyan Syafri Harahap, Analisis Kritis atas Laporan Kenangan (Jakarta :Rajawali Perss, 2010), hlm. 244.

${ }^{48}$ Kashmir, Analisis Laporan Kenangan, Jakarta :Rajawali Perss, 2010), hlm. 68-72.
} 
tertentu, yaitu perusahaan atau industri sejenis. Ada beberapa cara mendefinisikan istilah sejenis antara lain, (1) kesamaan jasa dan produk, (2) kesamaan sisi permintaan, serta (3) kesamaan atribut keuangan.

5) Analisis Time Series.

Merupakan teknik analisis laporan keuangan dengan cara membandingkan data historis keuangan dalam beberapa periode tertentu. ${ }^{49}$ Analisis Time Series mempunyai empat pola pergerakan yaitu, Trend, Siklus, Musiman dan Ketidakteraturan atau Random. ${ }^{50}$.

6) Menggunakan Indikator Ekonomi Makro.

Hubungan antara besarnya pajak penghasilan yang diperoleh dalam suatu tahun dengan indikator-indikator ekonomi seperti tingkat inflasi, tingkat pengangguran dan cadangan devisa. Keandalan perumusan ekonometri ini akan membantu auditor atau investigator melalui data agregat, tanpa harus melakukan pemeriksaan SPT auditee.

e. Menghitung Kembali.

Menghitung kembali atau reperform tidak lain adalah pengecekan kebenaran perhitungan (kali, bagi, tambah, kurang dan lain-lain)

f. Laporan Akhir.

Isi Laporan akhir harus menjelaskan Informasi tentang berjalannya proses pemeriksaan akuntansi, termasuk ditemukannya kecurangan, informasi mengenai pelaku atau Profilling, ${ }^{51}$ motif dilakukannya kecurangan, waktu dan tempat kejadian kecurangan, bagaimana kecurangan dilakukan.

\section{2) Pemanfaatan teknik perpajakan.}

Teknik perpajakan biasa digunakan dalam pemeriksaan kejahatan terorganisisr dan penyeludupan pajak penghasilan.Teknik ini juga dapat diterapkan terhadap data kekayaan pejabat Negara. Ada dua macam teknik pemeriksaan perpajakan yaitu Net Worth Method dan Expenditure Method ${ }^{2}$ Net Worth Method adalah metode yang

${ }^{49}$ Dwi Prastowo dan Rifka Julianty, Analisis Laporan Kenangan: konsep dan aplikasi, (Yogyakarta : UPP AMP YKPN, Maret 2005), hlm. 244.

${ }^{50}$ Mamduh M. Hanafi dan Abdul Halim, Analisis Laporan Keuangan, hlm.137.

${ }^{51}$ Amin Widjaja, Forensic \& Investigative Accounting: Pendekatan Kasus, hlm. 25-26.

52Theodorus M Tuanakotta, Akuntansi Forensik, dan Audit Investigatif, hlm. 363. 
digunakan untuk menelusuri penghasilan yang belum dilaporkan oleh wajib pajak. Sedangkan Expenditure Method adalah metode yang digunakan untuk memeriksa wajib pajak yang tidak mengumpulkan harta benda, tapi dia mempunyai pengeluaranpengeluaran besar (mewah).

3) Penelusuran jejak-jejak arus uang.

Penelusuran jejak-jejak arus uang ini lebih dikenal dengan istilah follow the money. Follow the money secara harfiah berarti mengikuti jejak-jejak yang ditinggalkan dalam suatu arus uang atau arus dana. Dana bisa mengalir secara bertahap dan berjenjang, tapi akhirnya akan berhenti di satu atau beberapa tempat. Tempat perhentian terakhir inilah yang menjadi petunjuk kuat yang akan membawa kepada para pelaku Fraud. ${ }^{53}$

4) Penerapan teknik analisis hukum.

Dalam hal ini akuntan forensik harus mempunyai pemahaman tentang hukum pembuktian sesuai dengan masalah yang dihadapi, seperti tindak pidana umum, tindak pidana khusus, serta pencucian uang. Melalui analisis ini, akuntan forensik akan dapat mengumpulkan bukti dan barang bukti guna mendukung dugaan adanya perbuatan melawan hukum yang dilakukan para pelaku Fraud atau kecurangan.

5) Pemanfaatan teknik audit investigatif dalam pengadaan barang.

Pemeriksaan pengadaan barang ini merupakan suatu upaya untuk memastikan bahwa dana publik dibelanjakan dengan baik guna meningkatkan efektivitas operasional serta sesuai peruntukkannya.

6) Penggunaan Computer Forensic.

Ada dua pokok utama dalam computer forensic. Pertama, segi-segi teknis yang berkenaan dengan teknologi (komputer, internet dan jaringan) dan alat-alat (Windows, Unix, serta Disk drive imaging). Kedua, adalah segi-segi teknis hukum seperti penggeledahan dan penyitaan barang bukti. ${ }^{54}$

7) Penggunaan Teknik Interogasi.

Teknik interogasi ini dilakukan secara persuasif.Akuntan biasanya menggunakan taktik "membuat penyataan" dan bukan

${ }^{53}$ Ibid., hlm. 374.

${ }^{54}$ Theodorus M Tuanakotta, Akuntansi Forensik dan Audit Investigatif, hlm. 461. 
"mengajukan pertanyaan". Tujuannya tidak lain adalah untuk mengetahui detil lengkap tentang kejadian yang sebenarnya

8) Penggunaan Undercover Operations.

Undercover Operations adalah suatu kegiatan yang berupaya mengembangkan barang bukti secara langsung dari pelaku kecurangan dengan menggunakan samaran (disguise) dan tipuan (deceit).

9) Pemanfaatan Whistleblower.

Whistleblower diterjemahkan secara harfiah dengan istilah peniup peluit.Maknanya adalah orang yang mengetahui adanya bahaya atau ancaman dan berusaha menarik perhatian dengan meniup peluitnya.Meniup peluit disini digunakan dengan kiasan yang artinya adalah membuka aib dan membocorkan rahasia. Atau dalam istilah lain adalah pelapor pelanggaran.

\section{Simpulan}

Akuntansi forensik dan audit investigatif adalah serangkaian hubungan dalam pemeriksaan fraud. Fraud atau kecurangan adalah objek utama yang diperangi dalam akuntansi forensik dan dibuktikan dalam audit investigatif. Kecurangan adalah suatu pengertian umum yang mencakup beragam cara yang dapat digunakan oleh kecerdikan manusia, yang digunakan seseorang untuk mendapatkan keuntungan dari orang lain melalui perbuatan yang tidak benar. Fraud Triangle atau segi tiga fraud menggambarkan tentang penyebab terjadinya suatu tindakan kecurangan, seperti Pressure, atau adanya suatu tekanan, Perceived Opportunity, atau tersedianya peluang, serta Rationalization, atau pembenaran atas suatu kejahatan.

Sementara Akuntansi forensik adalah penggunaan keahlian akuntansi yang dipadu dengan kemampuan investigatif untuk memecahkan suatu masalah/sengketa keuangan atau dugaan fraud.Segitiga Akuntansi Forensik menghubungkan tiga aspek yaitu kerugian, perbuatan melawan hukum dan hubungan kausalitas.

Audit Investigatif secara sederhana dapat didefinisikan sebagai suatu upaya pembuktian atas suatu kesalahan sesuai dengan ketentuan hukum yang berlaku. Audit Investigatif diarahkan kepada pembuktian ada tidaknya fraud dan perbuatan melawan hukum lainnya. Ada tiga frand axioms atau aksioma fraud, yang Frand is hidden atau fraud selalu tersembunyi, Reverse proof atau pembuktian secara terbalik serta Existence of frand atau penetapan frand oleh 
pengadilan.Terdapat sembilan teknik audit investigatif, yaitu:Penggunaan teknik pemeriksaan laporan keuangan, Pemanfaatan teknik perpajakan, Penelusuran dengan follow the money, Penerapan teknik analisis hukum, Pemanfaatan teknik audit investigatif pengadaan barang, Penggunaan computer forensic, Penggunaan teknik interogasi, Penggunaan penyamaran, serta Pemanfaatan whistleblower atau pihak pelapor.

\section{Daftar Rujukan}

Association of Certified Fraud Examiners, Fraud Examiners Manual, 2006 edition.

Bachtiar, Emil, Kasus-Kasus Etika Bisnis dan Profesi ,Jakarta: Salemba Empat, 2012.

Barreveld, D. J, The Enron Collapse: Creative Accounting, Wrong Economic, or Criminal Acts, New York: Writer Club Press, 2002.

Bologna, G. Jack and Robert. J. Linquisdt, Fraud Auditing and Forensic Accounting: New Tolls and Techniques, John Wiley \& Sons, Inc., 1995.

Crumbley, D. Larry,Forensic and Investigative Accounting.USA :5 Agustus 2005.

Departemen Pendidikan dan Kebudayaan, Kamus Besar Babasa Indonesia, cet. II, Jakarta: Balai Pustaka, 1990.

Hanafi, Mamduh M. dan Abdul Halim, Analisis Laporan Kenangan, Yogyakarta : UPP STIM YKPN, Agustus 2007.

Harahap, Sofyan Syafri, Akuntansi Islam, Cet. I, Jakarta: Bumi Aksara,1997. , Teori Akuntansi, Jakarta: Rajawali Pers, 2008. , Analisis Kritis atas Laporan Keuangan, Jakarta :Rajawali Perss,

2010.

Harnanto, Analisis Laporan Keuangan, Yogyakarta : BPFE, 1987.

Kashmir, Analisis Laporan Kenangan, Jakarta :Rajawali Perss, 2010.

Ma'ruf, Muhammad, Tsunami Finansial: Peluang Bisnis dan Investasi Indonesia dan setiap Individu di Tabun 2009, Jakarta: Penerbit Hikmah, 2009.

Meliala, Adrianus, Praktek Bisnis Curang, Jakarta : Sinar Harapan, 1993.

Muhammad dan Alimin, Etika dan Perlindungan Konsumen dalam Ekonomi Islam, cet. I, Yogyakarta : BPFE, Februari 2004.

Pickett, K.H. Spencer dan Jennifer Pickett, Financial Crime Investigation dan Control.

Prastowo, Dwi dan Rifka Julianty, Analisis Laporan Kenangan: konsep dan aplikasi, Yogyakarta : UPP AMP YKPN, Maret 2005. 
Pusat Pelaporan dan Analisis Transaksi Keuangan, "Indonesia Melawan Praktek. Pencucian Uang, Jakarta: Maret 2003.

Setiawan, Dedhy, Yeni J, Liza A, Creative Accounting: Mengungkap Manajemen Laba dan Skandal Akuntansi, Jakarta: Salemba Empat, 2011.

Sidabalok, Janus, Hukum Perlindungan Konsumen di Indonesia ,Bandung : PT. Citra Aditya Bhakti, 2006.

Singleton, W. Tommie and Aaron J, Fraud Auditing and Forensic Accounting, John Wiley \& Sons, Inc., 2010.

Soejono, Karni, Auditing: Audit Khusus dan Audit Forensik dalam Praktek, Jakarta: Lembaga Penerbitan FE UI, 2000.

Soyomukti, Nurani dan Happy Nurwidiamoko, "Occupy W all Street” Dari Krisis Sistem Keuangan Amerika Serikat Menuju Gerakan Massa AntiNeoliberalisme, Malang: Intrans Publishing, 2012.

Sulistiawan, Dedhy Yeni Januarsi dan Liza Alvia, Creative Accounting: Mengungkap Manajemen Laba dan Skandal Akuntansi,Jakarta: Salemba Empat, 2011.

Tuanakotta, M.Theodorus. Akuntansi Forensik dan Audit Investigatif, Jakarta: Salemba Empat, 2010.

, Menghitung Kerugian Kenangan Negara dalam Tindak Pidana Korupsi, Jakarta: Salemba Empat, 2010.

Widjaja, Amin, Forensic \& Investigative Accounting: Pendekatan Kasus, Jakarta: Harvarindo, 2012. 